\title{
Beyond Compliance
}

\begin{abstract}
This book explores how ethics in organization can draw on research streams in moral philosophy and moral psychology in order to attune to the actual and concrete moral dilemmas in the workplace. Compliance activities in organizations often include ethical training of employees and formulations of codes of conduct to define required and expected behavior. In order to prepare leaders and employees for moral dilemmas in their professional lives, organizations need to go beyond compliance and acknowledge the complexity and ambiguity of the situations the employees can face. Familiarity with ethical tools, principles, and concepts can be part of a foundation for responsible decision-making, but only in tandem with empirical knowledge from social and moral psychology about judgment and decision-making.
\end{abstract}

Keywords Compliance $\bullet$ Organizational ethics $\bullet$ Moral psychology Moral reasoning $\bullet$ Professional ethics

We can understand moral reasoning at work to be the activity of judging and deciding what is morally right and wrong, permissible, obligatory, and forbidden in an organizational context. We can also place the activity under the heading of ethics in organizations. This book proposes a rethink of the assumptions this activity rests upon, in order to strengthen its potential to create responsible conduct in the workplace. It combines 
research streams in moral philosophy and in moral psychology to outline how it can be possible to attune ethics in organizations to the everyday tensions and dilemmas experienced by leaders and employees in work settings.

The first edition of this book was published as an Open Access title in 2015. It reached a wide audience of researchers, students, and practitioners. The book has been on the curriculum for Applied Business Ethics, a mandatory course for all Master of Science students at BI Norwegian Business School, where I teach. The revisions and additions of the current edition build on feedback from colleagues and students. One particular issue they have highlighted is a need for examples reflecting the ethical challenges that decision-makers in organizations are beginning to face with regard to digitalization and automation. In response to the feedback, the current edition contains one new chapter on the ethical dimensions of automation and artificial intelligence and another on organizational uses of social media. Both of these chapters include preliminary classifications of ethical dilemmas that arise in organizations when technology radically changes the scope of action within them. The examples in the other chapters have also been revised to be more in line with current ethical challenges in organizations.

Three assumptions about ethics in organizations are under scrutiny in this book. There are elements of truth in all of them, but they also tend to overshadow important aspects of the decision-making processes in organizations. The first assumption is that the development of skills to engage in ethical analysis can effectively prepare leaders and employees for the ethical challenges they will face at work. The second assumption is that decision-making should ideally rest with people of strong moral character, that is, with those who have a stable disposition to behave in a morally responsible manner, even when they are under pressure to do otherwise. The third and final assumption is that codes of conduct strengthen an organization's ability to deal with ethically challenging situations. The underlying problem with these three assumptions is that even an organization where the leaders and employees have been through ethical training and become familiar with ethical analysis, where the individuals are of reasonably good moral character, and where a detailed and concrete code of conduct is in place, is vulnerable to internal moral wrongdoing. This book attempts to address the limitations of the three assumptions and show how the combination of insights from moral philosophy and moral psychology can create a more robust ethics in organizations. 
Moral dilemmas are a pervasive feature in organizational life, and the discipline of ethics offers principles, tools, and concepts to analyze them and reach a decision about what to do. A moral dilemma is typically a situation where the decision-maker must choose between two or more options that represent some moral requirement or duty. The decision affects a range of stakeholders, and several of them can have reasonable moral claims to make on the decision-maker, but some of them will be disappointed. A moral dilemma is a choice between wrong and wrong. Something of moral value will be lost, no matter what the decisionmaker opts to do (Brinkmann, 2005; Kidder, 2005; Kvalnes \& Øverenget, 2012; Maclagan, 2003, 2012). Leaders and employees from the private as well as the public sector can experience that they spend their professional lives in a moral minefield. No matter where they put their feet, a moral dilemma can lay hidden and spring up to demand a swift response from them.

In the process of rethinking ethic in organizations we should be guided by a fundamental respect and understanding of the predicament of individuals who work under such conditions. Leadership research documents how important it is for employee motivation to experience that leaders and supervisors stand by their side and are supportive when they face the most stressful and demanding situations (Chughtai, Byrne, \& Flood, 2015), and moral dilemmas are concrete instances where such presence is pivotal. What individuals in professions as dissimilar as being a business manager and a social worker have in common is that they make decisions that can have considerable dramatic impact on other people. Their integrity, empathy, and common sense can be questioned and under pressure on a daily basis. Ethical perspectives on what goes on in organizations need to reflect the intense moral tensions experienced by the decisionmakers who operate there.

Ethics training has become an integral part of leadership and employee development programs in many organizations. Companies who are about to establish business in some of the most corrupt areas of the world send their people to anti-corruption training to prepare them for the realities they are about to face there. In many countries, professionals like accountants, lawyers, teachers, doctors, nurses, and financial advisors have ethical training as part of their obligatory continuing education. The expressed purpose of all these learning activities is to make the participants better equipped to meet ethically challenging situations at work. However, the distance between the harmonious teaching settings in the seminar room 
and the ambiguous and complex realities the participants face in their everyday work life can be considerable.

I have facilitated ethics sessions in organizations internationally for 18 years. In my experience, the commitment from participants and their bosses can range from intense all the way down to stone cold. In some organizations, ethics training becomes an arena for lively discussion of a broad range of professional issues, going well beyond the ethical. In others, the activity takes the form of compliance work that one reluctantly puts on the agenda and participates in with minimal engagement and effort. One accounting firm defines the main goal of an ethics course as fulfilling the requirement of having seven hours of ethics teaching for its partners. Not a word about substantial learning outcomes regarding the ability to cope with ethical challenges at work. If a company or group of professionals establish a code of conduct and invite their people to an ethics seminar, they can tick those two boxes on the compliance list. If things nevertheless go wrong, and individuals from the company become entangled in wrongdoing, the leadership can claim that those people have acted on their own behalf, and not in accordance with the intentions expressed during the ethics training.

In the courtroom, it can make a significant difference to the outcome for a company whether the employee who has bribed a public official on their behalf has been through ethical training or not. If he has, the company can distance itself from the critical event and claim that the person acted on his or her own, even though it has intentionally sent the employee on a mission into an area where wrongdoing appears to be inescapable. Incentives can be at odds with the messages from the ethics seminars, and the employees are expected to cope with that internal conflict.

Some of the ethical training sessions I have facilitated have been in the oil and gas industry. Since the early 1970s, my home country, Norway, has benefitted greatly from its natural resources in the North Sea. The income has financed the development of a well-functioning society, with excellent infrastructure in transport, health, and education. Norwegian oil and gas companies have also gradually developed competence and skills that have enabled them to pursue and establish business in other countries. Some of the world's richest oil and gas resources happen to be located in areas where corruption is commonplace, and the Norwegian companies have faced dilemmas in coping with that dimension of reality. In 2004, the company Statoil admitted that it had paid 15.2 million dollars to the son of the former president of Iran, with the aim of securing lucrative contracts 
in that country. As a result, the chairman, the CEO, and the director for international operations resigned, and the company received a heavy fine (BBC, 2004).

In the aftermath of the Statoil scandal, companies of all sizes and shapes in the oil and gas industry sat down to fine-tune their codes of conduct and invited leaders and employees to a range of extensive ethics seminars. I contributed to a series of these, in judgment and decision-making sessions focusing on how to cope with realistic dilemmas. The CEO of one of the companies participated on every session and gave an introductory talk at each of them. His main message to his traveling employees was: "Make sure you keep at arm's length from anything that smells of corruption." After that, he wished them a safe journey to Azerbaijan, Angola, Nigeria, and other countries where the company had activities.

How much should top management back home know about the complexities of business life and the level of corruption in the countries where their companies are active? When corruption cases come to trail, one of the key issues is often to settle whether top management knew about the transactions taking place. Legally, it is not enough to establish that they did not know. They may have chosen the stance of willful blindness (Heffernan, 2011), which involves taking conscious steps not to know, deciding not to inquire about how the company won a particular contract, which agents were involved, and about the details of the methods they deployed to get the attention of the local decision-makers. A CEO can decide to turn a blind eye to the details of the business culture and business methods his company partakes in, but that strategy is both ethically and legally dubious.

One group of professionals who have come under critical scrutiny after the financial crisis in 2008 is that of financial advisors. They have come under criticism for recommending and selling questionable products to their customers. The response from financial authorities in Norway and in other countries has been to tighten the control of the institutions and to demand that the financial advisors participate in ethical training. I have contributed to this activity at the business school where I work, by introducing ethical theories and concepts to financial advisors and inviting them to apply them to practical cases.

The creditable aim with these activities is to encourage ethical awareness in the profession and make the participants familiar with analytical tools with which to weight and consider their options. However, my impression is that the incentives these individuals encounter at work 
remain more or less unchanged, which means that the ethical training makes little difference to how they behave toward their customers. I ask the financial advisors what they would say to a customer under the following circumstances: Anne has recently inherited 200,000 Euro from an aunt and turns up for financial guidance. The advisor looks at Anne's overall financial situation and believes that the smartest thing this woman can do clearly is to use the entire inheritance to reduce her debt. However, this option will not give the advisor or his company any profits. He has a strong personal incentive to go against his own judgment of what would be the best option for Anne and advise her to spend the money on an investment package. What should he do?

When I put this question to the financial advisors, many of them appear to experience what $I$ in this book will call moral dissonance, a discrepancy between their moral convictions and what they are tempted or ordered to do. On the one hand, they want to live in accordance with the professional standard indicated in the title of being a financial advisor. Their primary goal should be to serve the client, the secondary goal to make profits. From a moral point of view, then, they realize that they should be honest to their customers and state frankly what they think would serve their personal economies best. On the other hand, their own income depends on sales of financial products, and their employers expect them to show good results. Anne may enter their office the day before the personal sales report for the month is due, and the advisor can be in a position where a sale to Anne will have a big positive impact on what happens in the meeting with the supervisor. In similarity to the corruption cases, top management seems to choose willful blindness over detailed knowledge of the practical consequences of the incentives they present to their employees, in the shape of the conversations that go on between their employees and customers.

Conflicts of interest are at the core of many ethical challenges in organizations (Nanda, 2002). The financial advisor can decide to give priority to his or her self-interest and the employer's interest ahead of the customer's interest, with very little risk of detection. A similar pattern is present in relations between professionals and their clients, customers, students, and patients in other setting. These situations are different from moral dilemmas, in that they do not pose a choice between options that are more or less on equal moral footing. They are not choices between wrong and wrong, but between one option that is morally obligatory and right, and another option that is tempting, but morally wrong. Professionals 
often have strong incentives to choose the morally wrong options, and when found out, face stern moral criticism. The public tends to expect and demand strength of character in the professionals, a disposition to withstand temptation to exploit their superior knowledge for personal gain. A call for more authentic leadership in organizations is also based on an assumption about firmness of character (Gardner, Cogliser, Davis, \& Dickens, 2011). Studies in social psychology suggest that such a reliance upon stable and robust moral standards in individuals is misplaced (Doris, 2002), and that organizations should instead attend to the incentives employees have for balancing between self-interest and client interest.

This book presents two streams of research and inquiry to support a rethink of ethics in organizations. The first is moral philosophy and ethics, which contributes with analytic tools to handle moral dilemmas and other challenging situations at work. I draw on classical contributions from Aristotle, Immanuel Kant, Jeremy Bentham, and John Stuart Mill, and contemporary input from Philippa Foot and Judith Jarvis Thomson, as well as a variety of more specific works in business ethics and organizational ethics. A central and original component in the book is the Navigation Wheel, a tool I have designed in collaboration with philosopher Einar Øverenget (Kvalnes \& Øverenget, 2012). Decision-makers can use the Wheel to keep track of the legal, ethical, value-oriented, moral, reputational, and economical dimensions of a decision. I have used in ethical teaching settings in a range of organizations, and the participants have appreciated it as a simple and practical tool with which to structure a conversation about right and wrong in work contexts.

The second stream of research is from moral and social psychology, in tandem with criminology. It explores the foundations of moral agency and attempts to identify the primary causes of moral wrongdoing. The traditional virtue ethics approach has been to explain moral transgressions and misconduct in terms of character defects. A person who gives in to temptation and prioritizes personal wealth over the legitimate claims of clients and customers is seen as a person of weak character, someone who has not developed a strong and stable disposition to do the right thing. An alternative circumstance approach has developed from experimental studies in social psychology, which indicate that aspects of a situation can have more predictive power in terms of right- or wrongdoing than information about the decision-maker's personality or character traits. Individuals may move from initial moral dissonance when facing an option that goes against their moral convictions, to acceptance of that option, through a process of 
moral neutralization. Circumstances, in terms of organizational climate and norms of communication among colleagues, can crucially affect whether a decision-maker either remains loyal to his or her moral beliefs or convinces himself or herself that it is acceptable after all to choose that option. The main instigators to this research stream have been Sykes and Matza (1957) and Bandura (1997), with more recent contributions from behavioral economics (Ariely, 2012; Mazar \& Ariely, 2010).

The major ethical scandals in business (Enron, Arthur Andersen, Parmalat) have all involved not just moral but also criminal wrongdoing. Ethics in organizations can thus learn from criminological studies of why people engage in lawbreaking activities. According to Heath (2008, p. 611), individual decision-makers "do not commit crimes because they lack expertise in the application of the categorical imperative or the felicific calculus. They are more likely to commit crimes because they have talked themselves into believing some type of excuse for their actions, and they have found a social environment in which this sort of excuse is accepted or encouraged."

Organizations can set out to build a communication climate where it is normal to challenge colleagues' justifications and excuses and people are encouraged to express their moral concerns and stay loyal to their moral commitments. In doing so, familiarity with Immanuel Kant's categorical imperative and other ethical concepts may actually be useful in articulating a position and arguing beyond an appeal to a gut feeling that one particular option is wrong. Ethics offers a vocabulary in which to voice a concern and challenge a decision that seems to be morally questionable. Psychology and criminology helps to understand how people of reasonably strong character and ability to reason about their choices can nevertheless become involved in serious wrongdoing.

The academic and practical contribution of this book is to combine two research streams to create a platform for responsible conduct in organizations. Training in ethical analysis, focus on moral character, and integration of codes of conduct are important to maintain normative standards in organizations, but even people with superior analytical skills who are strongly committed to an adequate set of moral values and take guidance from a set of codes and principles can become entangled in moral wrongdoing. Studies in moral psychology and criminology enlighten how this may happen and provide input on how to avoid it. These reflections are relevant both for how to conduct systematic ethics initiatives in organizations and for teaching of business and organizational ethics to students. 
It is not sufficient to make people familiar with ethical tools and principles and to attempt to isolate individuals of strong moral character to become the leading decision-makers. Insights from psychological disciplines indicate that collective justification processes can pave the way for wrongdoing. The main countermeasure can be to make it acceptable and normal to criticize moral neutralization attempts openly. When that happens, ethics in organizations move beyond compliance and fulfillment of external expectations to the serious everyday conversations about right and wrong.

\section{REFERENCES}

Ariely, D. (2012). The (honest) truth about dishonesty. New York: Harper Collins. Bandura, A. (1997). Self-efficacy: The exercise of control. New York: Freeman \& Company.

BBC. (2004, June 29). Statoil fined over Iranian bribes. Retrieved from http:// news.bbc.co.uk/2/hi/business/3849147.stm

Brinkmann, J. (2005). Understanding insurance customer dishonesty: Outline of a situational approach. Journal of Business Ethics, 61(2), 183-197.

Chughtai, A., Byrne, M., \& Flood, B. (2015). Linking ethical leadership to employee well-being: The role of trust in supervisor. Journal of Business Ethics, 128(3), 653-663. https://doi.org/10.1007/s10551-014-2126-7

Doris, J. M. (2002). Lack of character: Personality and moral behavior. New York: Cambridge University Press.

Gardner, W. L., Cogliser, C. C., Davis, K. M., \& Dickens, M. P. (2011). Authentic leadership: A review of the literature and research agenda. The leadership quarterly, 22(6), 1120-1145.

Heath, J. (2008). Business ethics and moral motivation: A criminological perspective. Journal of Business Ethics, 83(4), 595-614.

Heffernan, M. (2011). Willful blindness: Why we ignore the obvious at our peril. London: Walker Books.

Kidder, R. M. (2005). Moral courage: Taking action when your values are put to the test. New York: William Morrow.

Kvalnes, Ø., \& Øverenget, E. (2012). Ethical navigation in leadership training. Etikk i praksis-Nordic Journal of Applied Ethics, 1, 58-71.

Maclagan, P. (2003). Varieties of moral issue and dilemma: A framework for the analysis of case material in business ethics education. Journal of Business Ethics, $48(1), 21-32$.

Maclagan, P. (2012). Conflicting obligations, moral dilemmas and the development of judgement through business ethics education. Business Ethics: A European Review, 21(2), 183-197. 
Mazar, N., \& Ariely, D. (2010). Sequential influences on dishonest behavior. Advances in Consumer Research, 37, 143-145.

Nanda, A. (2002). The essence of professionalism: Managing conflict of interest. Division of Research, Harvard Business School.

Sykes, G. M., \& Matza, D. (1957). Techniques of neutralization: A theory of delinquency. American Sociological Review, 22(6), 664-670.

Open Access This chapter is licensed under the terms of the Creative Commons Attribution 4.0 International License (http://creativecommons.org/licenses/ by $/ 4.0 /$ ), which permits use, sharing, adaptation, distribution and reproduction in any medium or format, as long as you give appropriate credit to the original author(s) and the source, provide a link to the Creative Commons licence and indicate if changes were made.

The images or other third party material in this chapter are included in the chapter's Creative Commons licence, unless indicated otherwise in a credit line to the material. If material is not included in the chapter's Creative Commons licence and your intended use is not permitted by statutory regulation or exceeds the permitted use, you will need to obtain permission directly from the copyright holder.

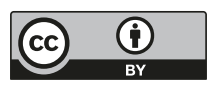

